\section{Inadequate Flexibility and Resistance to Change Hindering Effectiveness of ERP System in Accounting}

\section{Sherzad Ramadhan}

Bucharest Academy of Economics Studies (ASE), Romania

\section{Kamil Ghanim Ahmed}

Bucharest Academy of Economics Studies (ASE), Romania

\section{Hassan Koutaini}

Bucharest Academy of Economics Studies (ASE), Romania

\section{Ma'moun W. Aridah}

Bucharest Academy of Economics Studies (ASE), Romania

\section{Fareeba Ahmed}

Bucharest Academy of Economics Studies (ASE), Romania

Submitted: 16 November 2020

Accepted: 11 December 2020

Published: 31 December 2020

Corresponding author:

Sherzad Ramadhan

DOI: 10.19044/esj.2020.v16n34p25

(c) Copyright 2020 Ramadhan S. et. al. Distributed under Creative Commons BY-NC-ND 4.0 OPEN ACCESS

\section{Abstract}

The Enterprise Management Planning (ERP) software applications allow companies to integrate key daily activities such as procurements, financial, production, human resources, and project activities and helps organizational stakeholders to facilitate efficient decision making based on integrated data from various departments. Many accountants have not been able to realize the effectiveness of the ERP system due to its inadequate flexibility to adapt to change and resistance among some accountants that use the system. This research aims at showing the role that the inadequate flexibility of the system plays in impeding the ERP software from guaranteeing effectiveness and depicts how resistance to change among different stakeholders in an organization hinders the effectiveness of the enterprise resource planning (ERP) system in accounting. It uses a qualitative research method entailing semi-structured interviews with multiple employees working in the accounts department in different organizations. The study revealed that many accountants are driven by fear of new technology, making them resist the ERP system. Participants also affirmed that ERP does not readily adapt to organizational changes in the accounting departments. The major limitation of this study is that it focused on a small sample population because of the limited funds to cater to many participants.

Keywords: Inadequate Flexibility, Resistance, Enterprise Resource Planing (ERP), Information System 


\section{Introduction}

Enterprise Management Planning (ERP) is integrated software used by companies to manage critical business functions within an organization (Kanya, 2018). The Enterprise Management Planning (ERP) software applications allow companies to integrate key daily activities such as procurements, financial, production, human resources, and project activities (Kanya, 2018). It helps organizational stakeholders to facilitate efficient decision making based on integrated data and information from various departments. The ERP system automates complex corporate activities that often waste significant time and resources and other repetitive manual processes (Kanya, 2018). This makes business processes very efficient and allows different departments to conduct their duties without pressure, confusion, or bugging leaders. Nevertheless, Uppatumwichian (2013) argued that the ERP system's effectiveness depends on its flexibility to adapt to organizational changes and business processes. However, the EPR system is complex and rigid to change, forcing companies to spend substantial time and resources training workers to adapt instead of the system itself accommodating recent organizational changes that a company and the market present (Kanya, 2018). Also, resistance among employees and other corporate stakeholders to adopt the new integrated system deters the ERP software from achieving its objective of facilitating organizational efficiency in achieving goals.

This research aims to deconstruct the role that the system's inadequate flexibility plays in impeding the ERP software from guaranteeing effectiveness. It also aims at depicting how resistance to change among different stakeholders in an organization hinders the effectiveness of the enterprise resource planning (ERP) system in accounting. As corporates and small and medium businesses implement the ERP system to effectively automize critical functions to achieve efficiency and high productivity in firms, resistance to change, especially when adopting the new technology, significantly hinders the system from ensuring effectiveness. The unwillingness to accept the new technologies hampers the efficacy of a new system because people opt not to utilize the system leading to work-around and inevitably deteriorates the benefits a business can realize.

\section{Literature Review}

\section{ERP Effectiveness in Accounting}

Various organizations have adopted the ERP system because of its effectiveness in organizational operations such as accounting. According to the study conducted by Alrabba \& Ahmad (2017), the ERP system has increased the significance and relevance of the accounting information and decreased the uncertainties that hinder effective decision making in organizations (Alrabba \& Ahmad, 2017). The ERP systems have improved 
internal and external accounting information controls and helped create a clearer picture of organizations' accounting and financial position (Al-Akra et al., 2009). Also, Al-Akra et al. (2009) ascertain that ERPs have bookkeeping advantages, including better adaptability of data and enhanced financial reports, due to their modern bookkeeping methods. Heele (2019) also asserts that while standalone accounting packages provide the necessary accounting reports such as balance sheets and income statements, ERP systems offer a wide range of detailed financial information. For instance, ERP provides cashflow projections basing their forecasts on order statistics, inventory management, ledger management, and accounts receivables (Heele, 2019). Rich and widely-ranged financial reports enable the accounting department to account for all business finances. Heele (2019) adds that ERP systems have automated the accounting processes, facilitating easy entries and tracking financial transactions. The systems have made it easier to automate workflows that cross more than one system (Heele, 2019). Abbasi et al. (2014) affirm that ERP has simplified and streamlined the accounting processes such as accounts payable, accounts receivables, cash management, and cash flow problems. Moreover, according to Abbasi et al. (2014), ERP helps curb accounting errors such as duplicate data entries. It also integrates all accounting information, removing the tedious manual data entry process prone to mistakes (Abbasi et al., 2014). Further, the ERP system is highly reliable as it is accurate and ensures the timely integration of data and real-time financial reports that facilitate better decision-making (Abbasi et al., 2014).

\section{Inadequate Flexibility}

Accounting organizations or departments implement ERP systems to ensure they help achieve organizational goals as they integrate and manage critical corporate functions (Abas, 2018). However, Enterprise Management Planning (ERP) depicts inflexibility, which critically hinders its effectiveness from achieving desired organizational goals and objectives. Inflexibility entails unwillingness to compromise or an inability to change (Abas, 2018). An ERP system is designed to provide centralized information based strictly on configured data and commands. It allows access to stored data from robust databases to offer solutions to intended organizational problems. However, the ERP systems can perform powers and functions they are aligned with, but they cannot adapt to new changes (Abas, 2018). The inadequate flexibility of the ERP system places a limitation on the range of solution a company can attain or put into perspective (Abas, 2018). For example, it is difficult to change or adjust the ERP system to adapt to organizational changes or new business processes, which hinders companies from attaining their stipulated objectives. Uppatumwichian (2013) highlighted limited consistency in ERP utilization in managing accounting functions due to its rigidity. Since the ERP system 
functions to promote effectiveness, its inflexibility poses a challenge to these companies. This is because it requires sophisticated integration between diverse business systems with the ERP central system to align the data workflows and pre-existing processes (Abas, 2018). Businesses are susceptible to change to adapt to the fluctuating market demands, growth, and development, which require a system that quickly embraces changes. However, adjusting the ERP system and setup involves writing custom codes and configured data within the database (Abas, 2018). This inflexibility hinders the effectiveness and efficacy of the ERP to facilitate organizational goals.

Uppatumwichian (2013) ascertained that the ERP system lacks the flexibility that organizations need, especially during business processes such as accounting. The system is either slow or does not correspond to the changing modes and networks that companies adopt, which hinders strategic business initiatives. Since the implementation of an ERP system aims to help organizations achieve their goals, the inability to efficiently correspond to networking modes substantially deters goal achievement (Uppatumwichian, 2013). Inadequate ERP system flexibility can result in direct risks for companies because the system's reference model does not readily embrace the changing business environment to facilitate suitable processes and changes (Uppatumwichian, 2013). This forces companies to change and reformulate their strategies to adapt to the ERP system. For example, as accountants strive to achieve organizational objectives, they encounter difficulty with the inflexible ERP system (Kanya, 2018). The inadequate flexibility in the system wastes significant time and resources, as organizations must retrain employees to adapt to the system's rigid nature rather than promoting its effectiveness or ensuring recognition of business (Kanya, 2018). Therefore, the system's inadequate flexibility to accommodate organizational changes and new business processes hinders ERP systems' effectiveness, making them a liability rather than an asset to companies.

\section{Resistance to Change}

Resistance to change has been defined as a natural reaction that employees develop in response to change (Schein, 1993). Ahmed et al. (2006) described resistance as a phenomenon that daunts the change process, either by slowing or delaying its beginning, increasing its costs, or obstructing its initiation or implementation. According to Chawla and Kelloway (2004), resistance is both a behavioral and attitudinal response to change. Employees may not be resisting the change, but instead, they may be fighting the cost, loss of status, or discomfort it brings(Chawla \& Kelloway, 2004). Most departments face difficulty implementing changes due to the strong resistance they get from the employees. Accounting is a sensitive department in every 
organization that requires cooperation from all employees when initiating any changes that would alter the normal accounting operations (Angonese \& Lavarda, 2013). However, the ERP system's implementation in accounting has faced resistance from the staff and employees, impairing its effectiveness.

Although ERP comes with numerous benefits to the organization, users still resist the system for multiple reasons. Angonese and Lavarda (2013) asserted that the primary factor that elicits resistance among employees is ontological insecurity that develops into anxiety. Schein (1993) defined stress as that feeling that arises due to the unwillingness or inability to learn or do something new because of the fear of the activity's complexity. In a study conducted by Angonese and Lavarda (2013), employees developed resistance to new accounting systems because of the fear of disruption. Additionally, according to Granlund, "management accountants tend to resist changes to the accounting system because they are now afraid that any single change would significantly affect their workload" (2001, p.150). Management accountants and employees are afraid that the unsuccessful implementation of a new system will be hazardous, considering the complexity of the ERP system (Granlund, 2001).

Additionally, Seo (2013) explained that the other key factor that causes resistance to the new ERP system in accounting is the change itself. The management and employees have work habits and patterns that are interfered with when the new system is implemented. Schein (1993) confirmed that a lack of willingness to embrace change inflicts resistance among the accounting workforce. Additionally, employees tend to be unwilling to implement ERP because it requires new abilities and skills. Seo (2013) explained that in the case of post-ERP implementation resistance, employees find the new system to be misaligned with their expectations, training, education, and skills. Also, fear of inability to implement a new system due to lack of experience, training, and IT skills, and the change process's ambiguity contributes to the resistance (Seo, 2013).

Furthermore, organizations are shaped by their environment, which constitutes imposed rules, myths, cognitive patterns, and social expectations of the parties involved (Angonese \& Lavarda, 2013). Successful implementation and utilization of the ERP require the organization to equip employees with the necessary skills and knowledge of the system that draws the correct cognitive patterns (Angonese \& Lavarda, 2013). A lack of knowledge about the ERP system and its potential benefits in the accounting process induce resistance from the accounting workforce. Granlund (2001) explained that, during the ERP system's implementation, the workforce's knowledge and skills are ignored, which results in increased resistance from the members. The people who institute change in an organization must have the knowledge and skills to ensure successful implementation. The lack of 
knowledge acts as a critical resistance factor during ERP systems' performance and utilization in the accounting process (Angonese \& Lavarda, 2013).

Nevertheless, resistance to change to accounting systems is undesirable due to the time and resources spent to ensure the successful implementation of new systems and processes (Granlund \& Mouritsen, 2003). While ERP is perceived as an effective system that increases efficiency in performing various business operations, increased resistance hinders full exploitation of the system's benefits. Despite the significant advantages and attributes presented by the systems, the ERP software's implementation and utilization have not been very successful in accounting due to the workforce's constant resistance (Chawla \& Kelloway, 2004). Although the ERP system could transform and streamline the accounting process, the workforce's opposition has resulted in its underutilization, thus hindering the system's effectiveness (Chawla \& Kelloway, 2004). This is because employees tend to avoid using ERP when they do not like the system or do not feel comfortable using it (Chawla \& Kelloway, 2004). Krasner (2004) ascertained that it takes numerous months for employees to get used to a new system and be comfortable using it after its implementation. However, with the complexity and system failures associated with ERP use, most accounting department employees tend to completely resist the system, which has resulted in its underutilization (Chawla \& Kelloway, 2004).

\section{Theoretical Framework}

The socio-technical theory argues that the organizational systems' performance and structure can only be understood and enhanced if both the technical and social aspects are put together and considered "interdependent parts of a complex system" (Appelbaum, 1997). According to Appelbaum (1997), the failure of most complex systems in the organization is caused by the products' social and technical aspects. Therefore, according to the author, when ensuring successful implementation of the system, it is essential to identify both the technical and social aspects affecting their functioning in the organization (Appelbaum, 1997). 


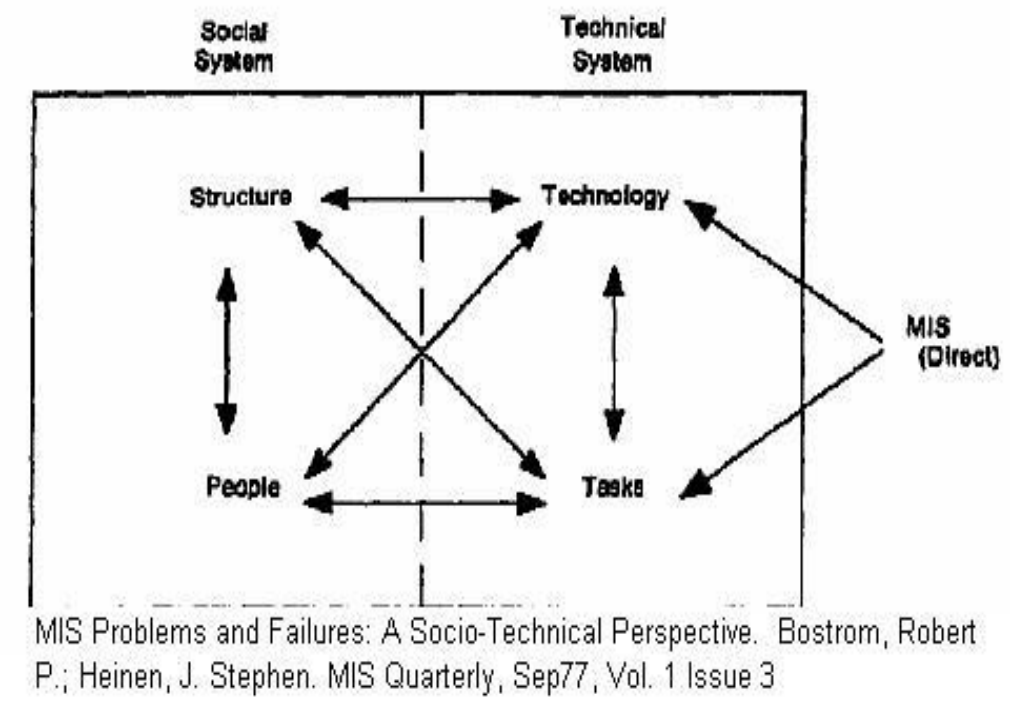

\section{Conceptual Framework and Hypotheses}

This study explores the impact of the system's inflexibility and employee's resistance to the system's effectiveness. The conceptual framework for this study is drawn from the literature review above. Based on the discussion above, inadequate flexibility and resistance to change significantly hinder the ERP system's effectiveness in accounting. Below is an illustration of the conceptual framework for this study.

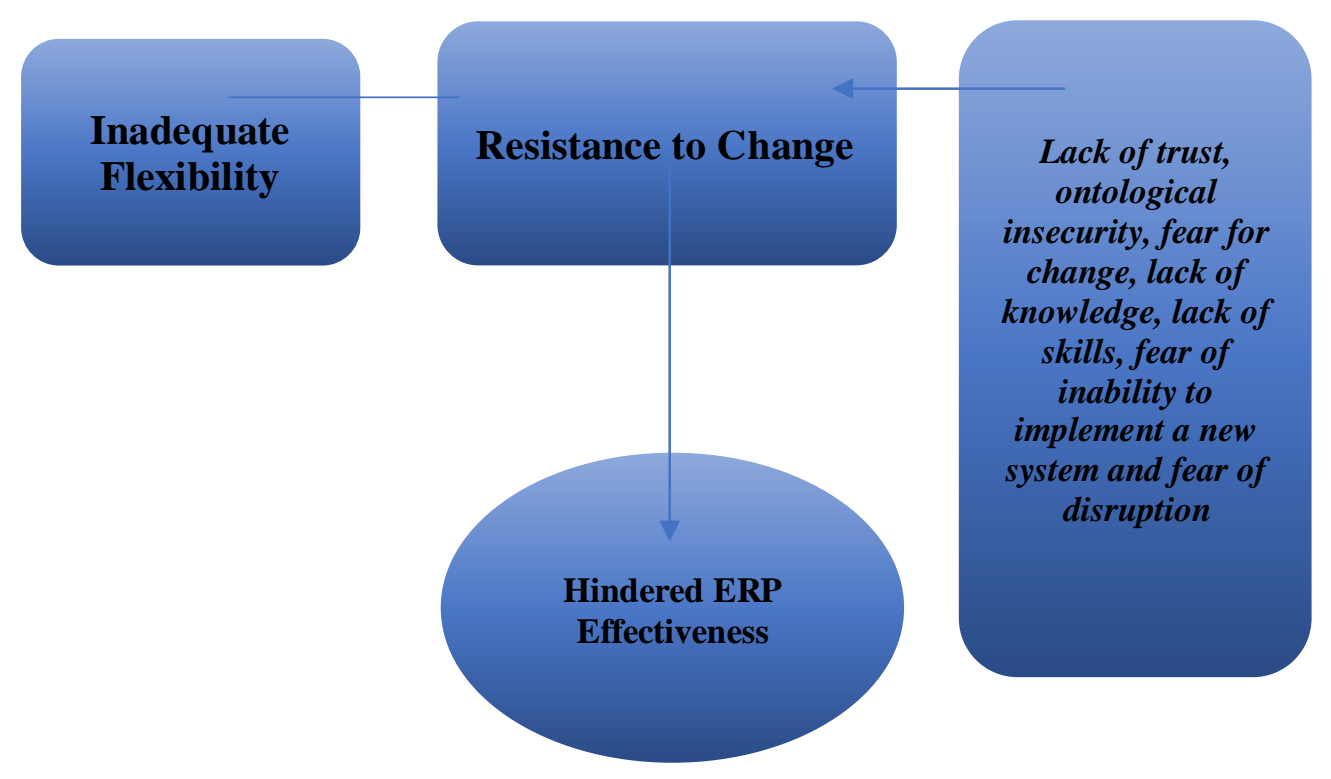


Accordingly, the hypotheses for this study are;

H1. Inadequate flexibility hinders the effectiveness of the ERP system in accounting

H2. Lack of trust, ontological insecurity, fear for change, lack of knowledge, lack of skills, fear of inability to implement a new system, and fear of disruption are central to increased ERP system implementation resistance. H3. Resistance to change hinders the effectiveness of the ERP system in accounting.

\section{Methodology}

The research involved an empirical study to investigate the impact of inadequate flexibility and resistance on the ERP system's effectiveness in the accounting process. The research utilized a qualitative two-phase survey to test the conceptual framework. The focus for phase I was a group of IT professionals and managerial accountants from various organizations. This phase gave insights into the inflexibility of the ERP system from an IT professional perspective. This study's second phase entailed semi-structured interviews with multiple employees working in the accounts department in different organizations. The phase entailed analysis of the resistance to change and effectiveness of ERP.

\section{Sample}

This study's sample population entailed an accounting workforce in 7 American companies (labeled A to G) that have implemented ERP or plan to implement the new system in accounting. The study conducted a web search to identify the top ERP consultants in the US. We placed the first two consulting companies on the list from the web search and sent emails to their managers requesting the names of the companies situated in America that had already implemented ERP or were planning to implement ERP, based on their data. The study identified fifteen companies in America, but only seven responded to the emails sent to them requesting interviews. Five of the companies selected for this study are among the most extended ERP system users. The remaining two organizations have been inquiring about the system from the ERP manufacturing and selling companies. A total of 10 accounting personnel, two from each of the organizations, were randomly selected from the accounting departments' workforce. The study also involved 7 IT professions randomly selected from the identified organizations.

\section{Data Collection and Analysis}

During the study, the researchers collected data using semi-structured interviews. It heavily involved all the study participants, which helped acquire enough data to test the conceptual framework and the hypotheses. The 
researchers transcribed all the data collected from the interviews and organized into themes relevant to the study. Data from phase 1 were reviewed, annotated, and conceptualized manually. In this phase, the researchers conducted a narrative analysis for all interviews. During the investigation, the researchers reviewed all the talks to familiarize themselves with the responses. The researchers highlighted all critical aspects of the stories that best resonate with the study and concluding based on the accounts. However, in phase 2, the data was large scale; hence it utilizes the Nvivo software to analyze and code the data into different themes. In this phase, the researchers only conducted a narrative analysis of five randomly selected interviews to examine the level of resistance among accounting professionals. During the investigation, the researchers reviewed and underlined the useful transcripts and the statements at first glance. The study identified common and recurring themes by assessing the number of times they appeared in the interviewees' responses and transcripts structured using a color scheme to create categories. Statements, quotes, and opinions were summarized into categories and subcategories in the order of their colors. After manual coding of the transcript, statements were collected, analyzed, and interpreted to identify the causes for resistance to change and ERP's effectiveness.

\section{Measures}

The study used an ordinal scale to measure the variables of this study. The ordinal scale ranges for the variables varied. The researchers sent a questionnaire constituting the scale to all participants through their emails. For ERP's effectiveness, the question stated, "How effective is the ERP system in accounting?" The scale measurement entailed; 1. very ineffective, 2. Somewhat ineffective, 3. Neutral, 4. Somewhat useful, and 5. Very effective. The question for resistance to change states, "Do you agree that accountants are resistant to ERP use and implementation?". The measurement scale constituted 1. Strongly disagree 2. Disagree. 3. Neutral, 4. Agree. 5. Strongly disagree. To measure inadequate flexibility, the question stated, " How inflexible is the ERP system in operationalizing accounting processes?" 1. Very inflexible. 2. Inadequately flexible. 3. Neutral. 4. Flexible. 5. Very flexible. The researchers assessed responses, and the total number for each response identified. Although the ordinal scale's unequal distance between its measurement points limits its reliability, it is a useful measurement that forces participants to differentiate various factors through ranking (Fife-Schaw, 2006).

\section{Reliability and Validity}

This study's reliability depends on the semi-structured interviews were general, as shown in the appendix, and follow-up questions were asked to 
further probe into the underlying problem under study. Additionally, the Nvivo software is a reliable tool that codes transcribed data and organizes it into themes. Hence the data analyzed using Nvivo is trustworthy and reliable. The examination of the articles can establish the validity of the study. The researchers critically reviewed Phase 1 results to identify all the critical information vital for the study. For step 2, themes were established before and after analysis to test their validity. Before coding, coders found the themes in the transcript, and after setting the coding scheme, they went through the transcripts to identify discrepancies or additional themes. The themes identified initially before software analysis were included in the coding scheme, and there were no other themes that had been overlooked, which proves the validity of the themes identified by the software.

\section{Results}

\section{Inadequate flexibility of the ERP system}

This theme entails the issues related to the inadequate flexibility of the ERP system itself that hinders its ineffectiveness in accounting. According to the ordinal scale, nine respondents claimed the system was inadequately flexible, four were neutral, and three claimed it was inflexible. During the interviews, the major complaint was the misfits or misalignment of the ERP'S built-in processes and the traditional accounting processes. Five of the study companies have pre-packaged ERP systems that came with standard business processes, but they are not adequately flexible for accounting. Although there were numerous responses from the 7 IT professionals, only 2 provided a straightforward narrative of the inadequate flexibility of the system as the rest failed to clearly explain why ERP was not flexible.

"ERP flexibility is essential, but it is not as simple to attain it as it seems. For instance, it is difficult to alter the systems architecture to fit an organization's changing needs as the system's cloud solutions are very dependent on ERP's underlying platform configurations and infrastructure," said the IT director for company B.

The IT analyst for company $\mathrm{F}$ claimed;

"The ERP system is not adequately flexible. It requires a lot of time and resources to reorganize the business to fit the operation of the software."

The accounts managers expressed their frustrations about the ERP system's inadequate flexibility. I found responses from three accounts manager to be elaborative of the impact the inflexibility has had on the system's effectiveness in accounting.

The accounts manager for company $\mathrm{F}$ stated,

"The ERP system is quite a problem solver, it has reduced our workload, made data analysis easier, faster, and accurate, and we found new ways of working with the system. But the problem is that it is hard to do things 
differently in the ERP system because most of its programs are either rigid or hard to change. Just an example, the business calendar configured in our ERP system is not that compatible with our accounting calendar. Accounting is not constant; we can wake up one day and decide to close books weekly, daily, or even hourly, and it is not easy making frequent changes to the system. We decided to scrap the system for a time because it was too costly, and it could not adhere to the changing accounting operations in our company. We still use it, but the time and energy needed to realign the system always sends us back to our conventional accounting processes. we have to stop using the ERP system for a few days for it to be reprogramed, which makes it less effective as it causes disruptions and inconveniences."

The accounts manager for company B claimed that;

"We rarely use the system because our department is like a business silo. But the ERP system has been programmed to integrate all departments within the organization. If there was a way we could reprogram the system, we could, but the specific program is rigid; it will be like reinstalling different software. We do not like sharing most of our information with the rest of the company, so we do upload only a segment of our information in the system."

During the conversation with the accounts manager in company G, it was so evident that he was very frustrated with ERP's inflexibility;

$I$ needed more straightforward and simplified operations in accounting. With ERP, I knew it was possible to initiate institution-wide budgeting of all funds without making errors and wasting time. I expected a lot from the system, from the retrieval of account-based information to accounting professionalization. But instead of easing our work, the system is annoying and frustrating because we have to deal with an entirely new way of accounting. A good example is that a time-phased-budgeting has been integrated into the system's architecture that cannot be changed. Yet, it sets limits on grant management processes that can be considered. We tried to reconfigure and align the internal control system with our operations, but it is so complicated, and we evened returned it to the vendor to reorganize it. The system requires a lot of time and professional expertise to reorganize and make it useful for our operations. My accountants are forced to use conventional methods to perform most of our accounting processes because they find it hard to adapt to the new accounting processes.

\section{Resistance to Change}

According to the nominal scale, ten agreed, six strongly agreed, and one was neutral. The second phase of the study revealed that the accounting professionals' resistance to the ERP system hinders its usage and thus its effectiveness in accounting. 5 out of 10 respondents showed their unwillingness to adapt to the new system despite its benefits and contributions 
that the system can have in their departments. Three of the respondents were members of the companies that have implemented an ERP system, while two were members of organizations planning to implement the system.

When asked whether they experience any form of resistance, some of the responses included;

Accountant in company B;

"I do not use the system, and neither am I planning to use it. It is complicated, and the fact that it is still a new system in accounting just scares me off."

Managerial accountant in company D;

"It's been a year since the system was implemented in my company, but I still find it difficult to use it in accounting. First of all, the system is a bit complicated to use, and secondly, I just do not trust the system. I am ok using Freshbooks and Quickbooks in case I need software because that is what I am used to."

Accountant in company G;

"I just don't want to use this system because it failed me a few times. It's been a while since I used it."

Managerial accountant in company A;

"My company has been planning on implementing this system, but I just find it hard using it in accounting. I do not have the skills to operate the system, and its arrival will just disrupt my normal operations in a bid to adhere to the new system's requirements. I am not sure if I will implement this new system in accounting."

Managerial accountant in company $\mathrm{C}$;

"Ifeel a strong resistance towards implementing this system; maybe I am just afraid of adopting the new system or am not sure whether I will be able to implement and work with the system in accounting. it may take me quite a long time to implement the system."

When asked why they were resisting the implementation of ERP systems in accounting, various themes were confirmed. These include the system's complexity, fear of adopting a new approach, lack of skills and knowledge, fear of disruption, lack of trust, fear for change, and fear of inability to implement a new system. There was no evidence to support ontological insecurity. More results on resistance to change are illustrated in the NVivo coding scheme. (See appendix B) 


\section{ERP Effectiveness}

According to the nominal scale, eight claimed ERP was somewhat effective; four claimed it was beneficial, three claimed it was relatively ineffective, and two were neutral. Based on the empirical study, ERP is useful software in accounting. When asked whether the system was effective in accounting, all the participants responded, "Yes." The reasons for the ERP system's effectiveness were analyzed using the Nvivo software, and various codes were identified to determine the themes (see appendix C). According to the analysis, ERP automates accounting processes, minimizes errors in accounting processes, provides more detailed financial reports, and is reliable.

\section{Discussion and Conclusions}

The study reveals that ERP effective in accounting processes. Based on the study, ERP has automated processes that make it faster and easier to conduct accounting processes. This is in line with Heele (2019), who argues that ERP systems have automated the accounting processes, facilitating easy entries, and tracking financial transactions. The empirical investigation also reveals that ERP has reduced errors in accounting processes and simplified detailed financial reports. As Heele (2019) affirms, ERP systems offer a wide range of detailed financial reports. Abbasi et al. (2014) also ascertain that ERP helps curb accounting errors such as duplicate data entries. Moreover, according to the empirical study, ERP is highly reliable as it is accurate, provides real-time data, and seamlessly integrates all accounting information. This study corresponds with Abbasi et al., 2014, who claimed that ERP is not only accurate but also ensures timely integration of data and real-time financial reports that facilitate better decision making. A literature review also reveals that the ERP system has increased the significance and relevance of the accounting information and decreased the uncertainties that hinder effective decision making (Al-Akra et al. 2009). The ERP systems have improved internal and external controls of the accounting information. They also create a clearer picture of organizations' accounting and financial position (Al-Akra et al., 2009). Further, ERPs have bookkeeping advantages, including better adaptability of data and enhanced financial reports due to their modern bookkeeping methods (Al-Akra et al. 2009).

This study's results reveal that the ERP system's inadequate flexibility continues to hinder its effectiveness in accounting. According to the IT professionals who participated in this study, the ERP system is not flexible enough to ensure business agility in the accounting process. This is in line with Uppatumwichichian (2013), who asserted that there is inconsistency in utilizing the ERP system due to its rigidity. Organizations face challenges fully implementing the system in accounting because of its inadequate flexibility. According to this study, the system can benefit accountants and make their 
work more comfortable, but its insufficient flexibility hinders its effectiveness. This study reveals that it takes a lot of time and effort to align the systems architecture to fit organizational needs as the system's cloud solutions are very dependent on ERP's underlying platform configurations and infrastructure. Abas (2018) argues that ERP requires sophisticated integration between diverse business systems with the ERP central system to align the data workflows and pre-existing processes. According to Abas (2018), businesses are susceptible to change, to adapt to the fluctuating market demands, growth, and development, which require a system that quickly embraces changes. However, adjusting the ERP system and setup involves writing custom codes and the migration of configured data within the database (Abas, 2018). Based on the empirical investigation, accountants are forced to stop using the system and go back to their conventional accounting processes whenever they find the system incompatible with their new operations and needs reorganization. According to the interviews' narrative analysis, some accounting departments opt to stop using the system entirely because of its rigid features like integration of all departments in an organization and its inability to adjust to the changing operations quickly to avoid disruptions and inconveniences. The system's inadequate flexibility hinders the accounting professionals from exploiting the full potential that the ERP presents, thus hindering the accounting system's effectiveness. As Kanya (2018) asserts, the inadequate flexibility in the system wastes significant time and resources, as organizations must retrain employees to adapt to the system's rigid nature rather than promoting the company's effectiveness or ensuring recognition of the business.

Furthermore, resistance to change that accounting professionals show is negatively correlated with the ERP system's effectiveness in accounting. According to the study, when employees showed resistance to the system, they either had second thoughts about implementing it or stopped using it. While ERP portrays numerous benefits to accounting, lack of implementation of use hinders its effectiveness. This finding is in line with Chawla and Kelloway (2004), who asserted that the workforce's resistance results in the underutilization of ERP, thus hindering the system's effectiveness. The authors also added that employees tend to avoid using ERP when they do not like the system or are not comfortable using it (Chawla \& Kelloway, 2004). Reasons for resistance in the study are consistent with the current literature. According to the empirical study, the system's complexity, fear of adopting a new system, lack of skills and knowledge, fear of disruption, and lack of trust. This in line with the findings from various studies in the literature that identify that lack of confidence, ontological insecurity, fear for change, lack of knowledge, lack of skills, fear of inability to implement a new system, and fear of disruption. 
The research affirms that inadequate flexibility of ERP and the resistance to change among accounting professionals hinders the effectiveness of the ERP system in accounting. Although ERP is an essential tool that can transform accounting operations, its inadequate flexibility and resistance to change prevent accountants from efficiently operationalizing their highly volatile duties. This study's findings highlight the reasons for the inflexibility and resistance to ERP that may help organizations in the journey to implementing effective systems in accounting. This study's major limitation is that it focused on a small sample population because of limited funds to cater to many participants. However, this research gives more in-depth insights into inadequate flexibility and resistance to ERP and how they affect the effectiveness of the systems in accounting. Although it bridges the gap in accounting, it also gives room for future research. For example, future research is still needed to identify the possible solutions to the problem of inadequate flexibility and resistance to change to facilitate ERP systems' effectiveness in accounting.

The empirical investigation helps solve this study's research problem. Based on the research findings, it is evident that the ERP systems are highly effective in accounting. However, inadequate flexibility and resistance to change hinder the effectiveness of this system as accounting professionals avoid its use and implementation. Therefore, to foster the point of the system, organizations need to implement strategies to overcome resistance to change among employees, while developers should adjust the system to make it more flexible.

\section{Conclusion}

This research study attempted to explore the experiences of accountants as they use the ERP system. The review of the literature reveals that the system has made accounting information more operational in every organization. An analysis of the study and literature review shows that the ERP system is reliable, minimizes errors, automates accounting processes, and provides detailed financial reports, making it useful in accounting. However, despite its usefulness in accounting, resistance to change and inadequate flexibility hinders the system's effectiveness. The participants suggested that the EPR system present significant difficulty in the semi-structured interviews as it is inflexible when injecting new changes in accounting operations. The results depict that many accountants either resist implementing the ERP system within their department or avoid using the system when conducting accounting duties such as preparing the company's sales reports. This is primarily because the system is inadequately flexible, preventing it from effectively facilitating organizational goals. The findings further suggest a possible connection between resistance to change and its ineffectiveness. 
Failure to implement or use the system continues to hinder the effectiveness of ERP in accounting processes. The researcher hopes that further research is conducted on the acute relationship between accountants' resistance to change and ERP's inadequate flexibility, and the system's inability to meet company objectives effectively.

\section{References:}

1. Abas. (2018). ERP flexibility is essential, but not as simple as it seems. Abas ERP. https://abas-erp.com/en/news/erp-flexibility-andupgradability-\%E2\%80\%93-embracing-change-sustainabletechnologyabas\#: : text=The $\% 20$ need $\% 20$ to $\% 20$ create $\% 20$ custom,able $\% 20$ to $\%$ 20easily\%20update\%20interfaces.

2. Abbasi, S., Zamani M. \& Valmohammadi, C. (2014). The effects of ERP systems implementation on managememt accounting in Iranian organization. Education Business and Society Contemporary Middle Eastern Issues, 7(4). DOI: 10.1108/EBS-03-2014-0020

3. Ahmed, Z., Zbib, I., Arokiasamy, S., Ramayah, T., \& Chiun, L. M. (2006). Resistance to change and ERP implementation success: The moderating role of change management initiatives. Asian Academy of Management Journal, 11(2),

1-17. https://www.researchgate.net/publication/43655794_Resistance_to_c hange_and_ERP_implementation_success_The_moderating_role_of_ change_management_initiatives

4. Al-Akra, Mahmoud, Muhammad Jahangir Ali, and Omar Marashdeh. (2009). Development of accounting regulation in Jordan. The International Journal of Accounting, 44, 163-186. https://ideas.repec.org/a/eee/accoun/v44y2009i2p163-186.html

5. AlBar, A. Hddas, $M \&$ Hoque, R. Enterprise resource planning system: Emergence, importance, and challenges. International Technology Management Review, 4(4). https://www.researchgate.net/publication/279515314_Enterprise_Res ource_Planning_ERP_Systems_Emergence_Importance_and_Challe nges/fulltext/55e4e6e908aede0b57358424/Enterprise-ResourcePlanning-ERP-Systems-Emergence-Importance-and-Challenges.pdf

6. Al-Okaily, A., Al-Okaily, M., Shiyyab, F., \& Masadah, W. (2020). Accounting information system effectiveness from an organizational perspective. Management Science Letters, 10(16), 3991-4000.

7. Alrabba, H. M., \& Ahmad, M. A. (2017). The role of enterprise resource planning (ERP) system in advancing the country of Jordan towards international standard accounting practices and accounting mechanisms. Risk Governance \& Control: Financial Markets \& 
Institutions,

https://virtusinterpress.org/IMG/pdf/rgcv7i2art8.pdf

8. Angonese R. \& Lavarda, C. EF (2014). Analysis of the factors affecting resistance to changes in management accounting systems. Department of Accounting, Regional University of Blumenau. https://www.scielo.br/pdf/rcf/v25n66/1519-7077-rcf-25-66-0214.pdf

9. Appelbaum, S. H. (1997). Socio-technical systems theory: an intervention strategy for organizational development. Management Decision. DOI: 10.1108/00251749710173823

10. Chawla, A., \& Kelloway, E. K. (2004). Predicting openness and commitment to change. The Leadership \& Organizational Development Journal, 25, 485-498. https://doi.org/10.1108/01437730410556734

11. Fife-Schaw, C. (2006). Levels of measurement. Research Methods in Psychology, 3, 50-63. https://us.corwin.com/sites/default/files/upmbinaries/9903_040472ch3.pdf

12. Granlund, M. (2001). Towards explaining stability in and around management accounting systems. Management Accounting Research, 12 (2), 141-166. https://doi.org/10.1006/mare.2000.0151

13. Granlund, M., \& Mouritsen, J. (2003). Introduction: problematizing the relationship between management control and information technology. European Accounting Review, 12 (1), 77-83. https://doi.org/10.1080/0963818031000087925

14. Heele, K. (2019). Benefits of using and ERP System for your accounting. Natonal Society of Accountants. https://www.nsacct.org/blogs/kent-heele/2019/07/16/benefits-ofusing-an-erp-system-for-your-

accountin\#: :text=An\%20ERP\%20system\%20ensures\%20that, gener ating\%20information\%20and\%20compiling\%20it.

15. Kanya, A. (2018 September). What is ERP, and why is it important for businesses? Business tech. https://www.hashmicro.com/blog/what-iserp/

16. Klaus, T., \& Blanton, J. E. (2010). User resistance determinants and the psychological contract in enterprise system implementations. European Journal of Information Systems, 19(6), 625-636. https://link.springer.com/article/10.1057/ejis.2010.39

17. Krasner, H. (2004). Ensuring e-business success by learning from ERP failures. IT professional, 2(1), 22-27. DOI: 10.1109/6294.819935

18. Schein, E. H. (1993). How can organizations learn faster? The challenge of entering the Green Room. Sloan Manage Review, 34 (2), 85-92. https://dspace.mit.edu/bitstream/handle/1721.1/2399/SWP3409-45882883.pdf 
19. Seo, G. (2013). Challenges in implementing enterprise resource planning (ERP) system in large organizations: similarities and differences between corporate and university environment (Doctoral dissertation, Massachusetts Institute of Technology). https://cams.mit.edu/wp-content/uploads/2013-07.pdf

20. Uppatumwichian, W. (2013). Understanding the ERP system use in budgeting. In Enterprise Information Systems of the Future (pp. 106121). Springer, Berlin, Heidelberg. https://hal.inria.fr/hal01484694/document

\section{Appendix}

\section{Phase I}

\section{Appendix A: Interview questions}

Has your organization implemented or plans on implementing the ERP system in accounting? How has it been?

Do you think ERP system is a problem solver for the accounting department?

Is the ERP system being implemented by organizations in accounting flexible? Why?

What are your thoughts on the ERP system?

\section{Phase II}

Has your organization implemented or plans on implementing the ERP system in accounting? Have you felt any form of resistance towards ERP implementation or use? Why?

Do you like the ERP system? Why?

Is the ERP system effective in accounting? Why

Do you think your management should pursue the successful implementation of ERP in accounting? why?

What are your thoughts on the ERP system?

Appendix B: ERP Coding Scheme

Research Question:Have you felt any form of resistance towards ERP implementation or use? Why?

\begin{tabular}{|c|c|c|c|c|}
\hline Code & Category & Subcategory & Theme & Key research terms \\
\hline $\begin{array}{l}\text {-do not want } \\
\text { the system } \\
\text { - do not use } \\
\text { the system } \\
\text {-do not like } \\
\text { the system } \\
\text {-hate the } \\
\text { system } \\
\text {-Feel strong } \\
\text { resistance } \\
\text { towards the } \\
\text { system }\end{array}$ & $\begin{array}{l}\text { Failure to } \\
\text { implement or } \\
\text { incorporate } \\
\text { ERP into } \\
\text { accounting } \\
\text { operations. }\end{array}$ & $\begin{array}{l}\text {-Not using already } \\
\text { implemented } \\
\text { ERP. } \\
\text {-Do not want the } \\
\text { system to be } \\
\text { implemented. }\end{array}$ & $\begin{array}{l}\text { Resistance to } \\
\text { change }\end{array}$ & -resist, like, hate \\
\hline $\begin{array}{c}\text {-Afraid of } \\
\text { the new } \\
\text { system. } \\
\text {-not sure } \\
\text { what damage }\end{array}$ & $\begin{array}{c}\text { Anxiety } \\
\text { among } \\
\text { employees }\end{array}$ & $\begin{array}{c}\text { Fear of the system } \\
\text { itself } \\
\text { Fear of the } \\
\text { possible }\end{array}$ & $\begin{array}{c}\text { Fear of } \\
\text { adopting a new } \\
\text { system }\end{array}$ & $\begin{array}{l}\text {-fear,anxiety, new } \\
\text { system }\end{array}$ \\
\hline
\end{tabular}




\begin{tabular}{|c|c|c|c|c|}
\hline $\begin{array}{c}\text { the new } \\
\text { system can } \\
\text { caue }\end{array}$ & & $\begin{array}{l}\text { consequences of } \\
\text { the system }\end{array}$ & & \\
\hline $\begin{array}{l}\text {-Hard to use } \\
\text {-complicated } \\
\text {-Stressful to } \\
\text { use }\end{array}$ & $\begin{array}{l}\text { Difficulty } \\
\text { operating the } \\
\text { system }\end{array}$ & $\begin{array}{l}\text {-Complex } \\
\text { configuration } \\
\text {-configured } \\
\text { accounting } \\
\text { process are hard to } \\
\text { follow }\end{array}$ & $\begin{array}{l}\text { the complexity } \\
\text { of the system }\end{array}$ & $\begin{array}{l}\text {-complicated, } \\
\text { difficult, hard, } \\
\text { stressful }\end{array}$ \\
\hline $\begin{array}{l}\text {-Do not } \\
\text { know how to } \\
\text { use } \\
\text {-No training } \\
\text {-no skills } \\
\text {-Not familiar } \\
\text { with the } \\
\text { system }\end{array}$ & $\begin{array}{l}\text { Unaware or } \\
\text { unable to use } \\
\text { the system }\end{array}$ & $\begin{array}{l}\text {-Have not } \\
\text { received training } \\
\text { on ERP } \\
\text {-Not informed } \\
\text { about the system } \\
\text { and its functions }\end{array}$ & $\begin{array}{l}\text { lack of skills } \\
\text { and knowledge }\end{array}$ & $\begin{array}{l}\text { Skills } \\
\text { Knowledge } \\
\text { Training }\end{array}$ \\
\hline $\begin{array}{l}\text {-disrupt } \\
\text { normal } \\
\text { processes } \\
\text {-Interfere } \\
\text { with the } \\
\text { normal } \\
\text { accounting } \\
\text {-it will } \\
\text { change } \\
\text { everthing }\end{array}$ & $\begin{array}{l}\text { Disruption of } \\
\text { normal } \\
\text { accounting } \\
\text { processes }\end{array}$ & $\begin{array}{c}\text {-Change normal } \\
\text { accounting } \\
\text { processes } \\
\text {-Disrupt } \\
\text { accounting } \\
\text { operations } \\
\text { Hamper some } \\
\text { accounting } \\
\text { processes- }\end{array}$ & $\begin{array}{ll}\text { Fear } & \text { of } \\
\text { disruption } & \end{array}$ & $\begin{array}{l}\text { Disrupt,interfere,cha } \\
\text { nge,disturb }\end{array}$ \\
\hline $\begin{array}{l}\text {-Cannot trust } \\
\text { a new } \\
\text { system with } \\
\text { accounting } \\
\text { processes } \\
\text {-not } \\
\text { confident } \\
\text { with the new } \\
\text { system } \\
\text {-cannot rely } \\
\text { on a new } \\
\text { system }\end{array}$ & $\begin{array}{l}\text { Trustworthine } \\
\text { ss of ERP } \\
\text { among } \\
\text { employees }\end{array}$ & $\begin{array}{c}\text { No trust } \\
\text { No confidence } \\
\text { Not reliable }\end{array}$ & lack of trust & $\begin{array}{l}\text { Trust, confident, } \\
\text { rely,reliable }\end{array}$ \\
\hline $\begin{array}{l}\text { Used to the } \\
\text { old } \\
\text { transaction } \\
\text { processing } \\
\text { system } \\
\text { Changing } \\
\text { the system } \\
\text { seems scary } \\
\text { Afraid of } \\
\text { changing the }\end{array}$ & $\begin{array}{c}\text { Scared of } \\
\text { adopting a } \\
\text { new system }\end{array}$ & $\begin{array}{l}\text {-Afraid of leaving } \\
\text { the traditional } \\
\text { system } \\
\text {-Scared of a new } \\
\text { system }\end{array}$ & Fear for change & $\begin{array}{c}\text { Scary, old } \\
\text { processes, afraid. }\end{array}$ \\
\hline
\end{tabular}




\begin{tabular}{|c|c|c|c|c|}
\hline $\begin{array}{c}\text { old } \\
\text { processes to } \\
\text { new ones }\end{array}$ & & & \\
\hline $\begin{array}{c}\text {-We may not } \\
\text { be able to } \\
\text { implement } \\
\text {-may not be } \\
\text { successful } \\
\text {-might fail } \\
\text { on us. }\end{array}$ & $\begin{array}{c}\text { worries of } \\
\text { possible } \\
\text { failure to } \\
\text { implementate } \\
\text { the system }\end{array}$ & $\begin{array}{c}\text { Afraid of possible } \\
\text { failures during } \\
\text { implementation } \\
\text { Afraidn of } \\
\text { possible failures } \\
\text { after } \\
\text { implementation }\end{array}$ & $\begin{array}{c}\text { Fear of inability } \\
\text { to implement a } \\
\text { new system }\end{array}$ & $\begin{array}{c}\text { Unable, not } \\
\text { successful, fail. }\end{array}$ \\
& & & \\
\hline
\end{tabular}

Appendix C: NVivo Coding Scheme

Research Question: Is the ERP system effective in accounting? Why?

\begin{tabular}{|c|c|c|c|c|}
\hline Codes & Category & Subcategory & Theme & Search Key terms \\
\hline $\begin{array}{c}\text {-easy to automate } \\
\text { workflows that require two } \\
\text { systems } \\
\text {-No more manual entries } \\
\text { Financial transactions } \\
\text { automated } \\
\text { Faster to use ERP } \\
\text { automated processes }\end{array}$ & $\begin{array}{l}\text { Automation } \\
\text { of financial } \\
\text { and } \\
\text { accounting } \\
\text { processes }\end{array}$ & $\begin{array}{l}\text { Automated } \\
\text { workflow } \\
\text { Automated } \\
\text { accounting } \\
\text { entries and } \\
\text { transactions }\end{array}$ & $\begin{array}{l}\text { Automated } \\
\text { accounting } \\
\text { processes }\end{array}$ & $\begin{array}{c}\text { Automatic, } \\
\text { manual, automatic } \\
\text { accounting }\end{array}$ \\
\hline $\begin{array}{c}\text { - integrates all accounting } \\
\text { operations } \\
\text {-can track down the source } \\
\text { of mistake in data entries } \\
\text {-no incorrest details or } \\
\text { transposed digits } \\
\text {-no calculation mistakes }\end{array}$ & $\begin{array}{l}\text { Reduced } \\
\text { chances of } \\
\text { occurrence of } \\
\text { errors }\end{array}$ & $\begin{array}{l}\text { Errors in overall } \\
\text { accounting } \\
\text { operations } \\
\text { Errors in data } \\
\text { entry. } \\
\text { Errors in } \\
\text { calculation } \\
\end{array}$ & $\begin{array}{l}\text { Minimal data } \\
\text { entry errors }\end{array}$ & $\begin{array}{l}\text { Errors, mistake, } \\
\text { incorrect. }\end{array}$ \\
\hline $\begin{array}{l}\text {-Has varied financial reports } \\
\text { - offers comprehensive } \\
\text { financial reports }\end{array}$ & $\begin{array}{l}\text { Wide-range } \\
\text { detailed } \\
\text { financial } \\
\text { reports }\end{array}$ & $\begin{array}{c}\text {-cashflow } \\
\text { projections } \\
\text { - ledger } \\
\text { management } \\
\text { - detailed report } \\
\text { from analysis of } \\
\text { accounts } \\
\text { receivables and } \\
\text { accounts payable }\end{array}$ & $\begin{array}{l}\text { More detailed } \\
\text { financial } \\
\text { reports }\end{array}$ & Financial reports \\
\hline $\begin{array}{c}\text {-Seamlessly integrates } \\
\text { accounting information } \\
\text {-Accurate } \\
\text {-Authetic } \\
\text {-Easy to forecast } \\
\text {-Real-time financial reports }\end{array}$ & Dependable & $\begin{array}{l}\text {-Accounting } \\
\text { accuracy } \\
\text {-financial } \\
\text { projections }\end{array}$ & Reliability & $\begin{array}{c}\text { Reliable, accurate, } \\
\text { seamless }\end{array}$ \\
\hline
\end{tabular}

